Eduarda Souza Dilleggi

(ㄱ) htps:///orid.org/0000-0003-0268-5632

Patricia Leila dos Santos²

Onttps://orcid.org/0000-0002-2229-886x

Fabio Scorsolini-Comin ${ }^{3}$

(-)https://orcid.org/0000-0001-6281-3371

\section{Associations between family environment resources and mental health problems in children}

\author{
Associações entre recursos do ambiente familiar e \\ problemas de saúde mental em crianças
}

DOl: $10.1590 / 0047-2085000000359$

\begin{abstract}
Objective: The relationship between mental health and contextual factors has been increasingly investigated in the scientific literature to identify elements that may configure themselves as protective. The present study aimed to identify what resources (activities, family outings, toys, material elements, and learning) were offered in the daily lives of children with mental disorders, and from this, verify whether the offer of such resources in the family was associated with areas of greatest damage relative to mental health problems. Methods: Thirty-three caregivers of/people responsible for children between 6 and 12 years of age with most frequent diagnoses in attention-deficit hyperactivity disorder and autism spectrum disorder seen at a general hospital participated. We used the Strengths and Difficulties Questionnaire (SDQ - parents version) and Family Environment Resources Inventory (RAF). Results: From a descriptive and correlational analysis, it was revealed that the more the mental health problems were present in children, the lower the family resources offer. Conclusions: The environmental resources offer proved to be protective for child development. Such findings are relevant to aid in outlining strategies for promoting mental health among children.
\end{abstract}

\section{KEYWORDS}

Family environment, children, mental disorders, protective factors.

\section{RESUMO}

Objetivo: As relações entre saúde mental e fatores contextuais têm sido cada vez mais investigadas na literatura científica no sentido de identificar elementos que possam se configurar como protetivos. Este estudo teve por objetivo identificar quais recursos (atividades, passeios com a família, brinquedos, elementos materiais e de aprendizagem) eram oferecidos no cotidiano das crianças que apresentam transtornos mentais e, a partir disso, verificar se há associações entre a oferta de tais recursos no ambiente familiar e as áreas de maior prejuízo em relação a problemas de saúde mental. Métodos: Participaram 33 cuidadores/responsáveis de/por crianças entre 6 e 12 anos de idade com diagnósticos mais frequentes de transtorno do déficit de atenção e hiperatividade e transtorno do espectro autista acompanhadas em um hospital geral. Foram utilizados: Questionário de Capacidades e Dificuldades (SDQ - versão pais) e Inventário de Recursos do Ambiente Familiar (RAF). Resultados: A partir de uma análise descritiva e correlacional, revelou-se que quanto mais problemas de saúde mental estão presentes nas crianças, menor é a oferta de recursos no ambiente familiar. Conclusão: A oferta de recursos ambientais mostrou-se protetiva para o desenvolvimento infantil. Tais achados são relevantes para auxiliar no delineamento de estratégias para a promoção de saúde mental destinada ao público infantil.

\section{PALAVRAS-CHAVE}

Ambiente familiar, crianças, transtornos mentais, fatores de proteção. 


\section{INTRODUCTION}

The bioecological model understands human development as a result of the interaction between the individual and the environment where he is, highlighting the influence of different contexts (family, school, work, culture) on the individual's formation. This model is based on the following four main pillars (or dimensions) to which theorists, researchers, and clinicians must be attentive: person, process, context, and time (PPCT), which have been employed in research ${ }^{1,2}$, and which take the childhood as a development scenario and the family as the overriding socialization context ${ }^{3,4}$.

The child (Person) establishes interactions with other elements, persons, objects, and symbols present in the different contexts in which he or she participates. Those interactions characterize what the bioecological model names proximal processes (Process), which during childhood occur mainly in the family and school context (Context) and have potential for promoting development and guiding it within a healthy or adaptive trajectory ${ }^{5,6}$.

Other contexts influence child development, such as parents' work, political and religious ideologies, access to services, the historical moment in which the person lives, and the life cycle stage in which given events occur (for example, mental illness will affect diversely a child and an adult, as well as the contexts in which they participate) ${ }^{7}$. These two last elements characterize the model's Time dimension ${ }^{3}$.

Studies about mental disorders in childhood have adopted the bioecological model as a theoretical framework to understand the influence of different personal, family, and environmental conditions on the development of those disorders, as well as the protective effects that some characteristics or events from the environment might establish $2,8,9$.

A home environment rich in interactions and stimuli can facilitate and increase the frequency of proximal processes, and establish protection mechanisms to the development put at risk by the occurrence of a mental disorder ${ }^{3,10-12}$.

During childhood, the family will offer different opportunities and experiences to the child, be they by interactions it establishes with this child (positive or not), by the variety of activities carried out at home and outside it (family outings and school, for example), or by the offer of toys and other resources that stimulate child development ${ }^{13,14}$. The opportunities, activities, and materials available for the child depend fundamentally on interactions, proximal processes. Thus, a positive family context (well organized, rich in material and emotional stimuli, included in or connected to other contexts - school and neighborhood, for example) contributes to the promotion of healthy development ${ }^{15-17}$.

There is a wide range of studies treating of child development, however, studies directed at understanding the different factors influencing the trajectory of children with mental disorders are more restricted. Such studies often investigate developmental milestones, in children without psychopathologies for example $e^{5,8,9}$.

In what concerns mental disorders in childhood, studies present incidence rates varying from $13.4 \%$ to $25 \%$ in the world ${ }^{18-20}$ and $19 \%$ and $29.7 \%$ in Brazil ${ }^{21}$, which evidences the need for studies that contribute to a better understanding of the theme and for identifying factors that may contribute to the prevention of mental disorders in childhood and to the good development of children affected by the problem.

Researchers reported that limited access to resources in the family environment can influence directly the health and the adaptive functioning of children, at the same time that it can compromise the role of parents in promoting development, for example, the interactions between the parents and the child ${ }^{22-24}$. They also observed that there is a difference in the offer of resources and materials by the parents or guardians, which varies according to socioeconomic characteristics of the family, their level of education, and cognitive functioning and behavior that the child shows, so that such resources will be more offered according to the family's most stable situation of life ${ }^{16}$.

If, on the one hand, the family environment is a key context for child development, in that it can present itself as protector for mental health problems, from the establishment of daily activities, routines, autonomy stimuli, joint activities, and interactions ${ }^{3,12,25}$, on the other, depending on the family characteristics, it might establish itself as a risk condition for the presence of mental disorders in childhood ${ }^{26}$.

The presence of a child with mental disorders in the family can modify the dynamics, routine, the interactions there present and their quality. These changes can lead to different scenarios, such as extra care by parents/guardians, as well as of supervision and monitoring offered to the children, or even promote distancing between those members, which may represent a risk for development ${ }^{27,28}$.

Among the characteristics present in the child, behavior problems, for example, can be seen as limiting factors for resource offer in several contexts, such as within the family environment and in the school context 27,29,30.

The presence of resources in the family environment is associated negatively with children's behavior problems, specifically with externalizing behaviors. Having toys, books, going for walks, and experiencing an organized routine contribute to the child's development, and therefore, should be present in the family environment $\mathrm{t}^{1,31-33}$.

Some studies have investigated the presence of resources in the family environment and their participation in child development amid contexts such as cerebral paralysis, school, and literacy ${ }^{10,11,34}$, however, how different stimuli, interactions, and opportunities present themselves in the child mental disorder remains obscure. 
Having the importance of proximal processes as a focus, and the need for opportunities for them to establish themselves, the relevance of the family as a context of development, peculiarities of the mental disorder in childhood, and prior evidence that stimuli present in the family environment can favor child development, was assured this investigation.

The present study aimed to identify what resources (activities, family outings, toys, material and learning elements) are offered in the daily lives of children that have mental disorders and, from this, evaluate if there exist associations between the offer of such resources in the family environment and areas of greatest damage relative to mental health problems.

\section{METHODS}

\section{Type of study and ethical considerations}

This is a cross-sectional study, descriptive and correlational. All participants received information on objectives, procedures, risks, and benefits of the study, clarification on their rights and as volunteers of the research, and signed the Informed Consent Form (ICF), containing the same information, in conformity with Resolution n $466 / 2012$ of the National Council of Health. The research project was presented to and approved by the ethics committee of the author's home institution.

\section{Participants}

Thirty-three caregivers of/people responsible for children in the six to 12 year age range participated. Those children were outpatients in child psychiatry at a general hospital in the state of São Paulo, Brazil. From the list of outpatients and appointments, we identified 51 caregivers/people responsible for the children, of which 36 were contacted; three of them did not accept to participate in the research.

The participants included in the study were over 18 years old, main caregivers or main people responsible for 6-to 12-year-old children diagnosed with a mental disorder by psychiatrists of the outpatient clinic. Exclusion criteria were the caregivers having mental disorders and those that had a child with other health conditions that could interfere with the family care and resource offer. The invitation for participation was carried out in the waiting room of the outpatient clinic and the participant was conducted to a room for clarifications on the research, signing of the consent form, and application of instruments, if willing to participate.

Most participants were mothers (78.8\%), followed by fathers (15.2\%), aged between 24 and 62 years old (mean = 37.6 years old; $\mathrm{SD}= \pm 8.6$ ), which lived with a partner $(75.8 \%)$. Most (84.8\%) had at least primary education, $15.2 \%$ with less than eight years of schooling. In regard to socioeconomic status, 21.2\% belonged to classes A and B (better economic condition), $54.6 \%$ class C, and $24.2 \%$ to classes D and E (more precarious condition), as per economic classification criteria of the Brazilian Association of Research Companies ${ }^{35}$.

The children seen had a mean age of 8.3 years old (SD $= \pm 1.86)$, most boys (30.3\%) and attending school (78.8\%). The most frequent diagnoses were Attention-Deficit and Hyperactivity Disorder and Autism Spectrum Disorder (both with 39.4\%).

\section{Instruments}

\section{Sociodemographic questionnaire}

A questionnaire composed of 25 questions was constructed to investigate personal data, level of education of people responsible for the child, family structure (number of people living in the house and who they were), and socioeconomic status of the family ${ }^{35}$.

\section{Strengths and Difficulties Questionnaire (SDQ - parents version)}

It was used to evaluate problems in child and youth mental health, as well as identify the child's areas of greatest difficulty. The questionnaire is composed of 25 questions, subdivided in five subscales assessing hyperactivity, emotional symptoms, conduct problems, relationship with peers, and prosocial behavior. The SDQ has items such as "Has a lot of worries, often seems worried about everything", which can be responded to by marking False, More or Less True, or True, corresponding to the values 0,1 , or 2 . The sum of scores allows classifying the child into Normal, Borderline, or Abnormal in each subscale and in the full scale ${ }^{36}$. The instrument's reliability rate for the study sample can be seen in table 1.

\section{Family Environment Resources Inventory (RAF)}

This is an instrument that assesses the family environment resources based on the bioecological development conception, considering the following three domains: resources that promote proximal processes, activities that stabilize the family life, and parental practices promoting the relationship between family and schoo ${ }^{17}$. The scale is applied through an interview organized into the following ten topics: recreational activities at home/neighborhood; family outings; scheduled and regular activities; joint activities at home, with parents/person responsible; availability of toys, newspapers, magazines, and books; school support and supervision; organization of schedules, and family gathered for routine activities. The result is expressed by the relative score in each one of the topics. Table 1 presents Cronbach alpha values for the sample of this study.

\section{Procedure}

Data collection - One researcher approached the participants in the psychiatry waiting room, invited them to the 
research, informed on ethical aspects, and collected the participant's signature of the consent form. After this procedure, the participant was conducted to a private room for interview and filling out of instruments. Aiming at standardizing the filling out, the researcher proceeded to the interview for the filling out of the sociodemographic questionnaire and the RAF, and then read the SDQ items and alternatives and recorded the participant's answer at the instrument.

Data analysis - The information was organized following instructions of the instruments and stored in a data bank. Analyses were performed in the SPSS software version 24.0 at a significance level of 0.05 . We calculated the frequency and percentage of categorical variables and measures of central tendency for the numeric variables. To verify associations between mental health problems (SDQ) and resource availability in the family environment (RAF), we applied the Spearman correlation test. The associations interpretation occurred by way of the scientific literature in the area, in which weak correlations were those with values $<0.4$, moderate with values $\geq 0.4$ to $<0.5$, and strong the ones that showed values $\geq 0.5^{37}$.

Table 1. Cronbach Alpha for the instruments used

\begin{tabular}{ll}
\hline \multicolumn{1}{c}{ Dimension } & Cronbach Alpha \\
\hline SDQ & \\
Emotional symptoms & 0.37 \\
Conduct problems & 0.45 \\
Hyperactivity & 0.42 \\
Relationship with peers & 0.50 \\
Prosocial behavior & 0.69 \\
RAF & \\
Recreational activities at home/neighborhood & 0.73 \\
Family outings & 0.73 \\
Scheduled and regular activities & 0.75 \\
Joint activities with parents at home & 0.72 \\
Toys & 0.72 \\
Newspapers and magazines & 0.74 \\
Books & 0.73 \\
School support and supervision & 0.75 \\
Organization of schedules & 0.72 \\
Family gathered for routine activities & 0.74 \\
\hline
\end{tabular}

\section{RESULTS}

All SDQ results were considered abnormal (total scores above 17), considering the instrument's general score. Three percent of the children were observed to have commitment in all subscales (emotional symptoms, conduct problems, hyperactivity, relationship problems with peers, and prosocial behavior); $30.3 \%$ in four of them; $30.3 \%$ in three;
$24.2 \%$ in two, and $3 \%$ in only one subscale. According to the impact supplement of SDQ (which evaluates how much the difficulties affect the child's daily life), $48.5 \%$ of the parents note that the mental disorder affects the routine at home (a lot or more than a lot), $48.5 \%$ mention damage as to the child's friendships, $72.8 \%$ identify interference with learning, and $36.4 \%$ with leisure activities (Table 2). A higher average score was observed as for hyperactivity symptoms, and also for the presence of prosocial behavior (Table 3).

Concerning the RAF results (Table 4), the most present resource in the family environment were toys, followed by family gathered for routine activities and the carrying out of joint activities of the child with the parents, organized

Table 2. Frequency (f) and percentage (\%) regarding child's mental disorder impact on the home, friendships, learning, and leisure

\begin{tabular}{lcccccc}
\hline & \multicolumn{2}{c}{ Nothing/little } & \multicolumn{2}{c}{ A lot } & \multicolumn{2}{c}{ More than a lot } \\
\cline { 2 - 7 } & $\mathbf{f}$ & $\mathbf{\%}$ & $\mathbf{f}$ & $\mathbf{\%}$ & $\mathbf{f}$ & \% \\
\hline At home & 17 & 51.5 & 11 & 33.3 & 5 & 15.2 \\
Friendships & 17 & 51.5 & 9 & 27.3 & 7 & 21.2 \\
Learning & 9 & 27.3 & 12 & 36.4 & 12 & 36.4 \\
Leisure & 21 & 63.6 & 9 & 27.3 & 3 & 9.1 \\
\hline
\end{tabular}

Table 3. Minimum and maximum scores, mean, and standard deviation (sd) of results regarding children's strengths and difficulties (SDQ subscales)

\begin{tabular}{lccc}
\hline & Minimum & Maximum & Mean ( \pm sd) \\
\hline Emotional symptoms & 0 & 10 & $4.9( \pm 2.49)$ \\
Conduct problems & 0 & 10 & $4.3( \pm 2.38)$ \\
Hyperactivity & 6 & 10 & $8.9( \pm 1.33)$ \\
Relationship problems with peers & 0 & 10 & $4.2( \pm 2.71)$ \\
Prosocial & 0 & 10 & $8.8( \pm 3.22)$ \\
Total & 19 & 39 & $29.2( \pm 4.82)$ \\
Impact supplement & 0 & 9 & $3.4( \pm 2.77)$ \\
\hline
\end{tabular}

Table 4. Minimum and maximum scores, mean, and standard deviation (sd) of results regarding family environment resources (RAF)

\begin{tabular}{lccc}
\hline & Minimum & Maximum & Mean $( \pm \mathbf{s d})$ \\
\hline $\begin{array}{l}\text { Recreational activities at home/ } \\
\text { neighborhood }\end{array}$ & 1.4 & 10.0 & $5.1( \pm 2.13)$ \\
$\begin{array}{l}\text { Family outings } \\
\text { Scheduled and regular }\end{array}$ & 0.5 & 6.8 & $3.5( \pm 1.82)$ \\
$\begin{array}{l}\text { activities } \\
\text { Joint activities with parents at }\end{array}$ & 0.9 & 9.4 & $0.8( \pm 1.11)$ \\
home & 2.6 & 10.0 & $6.0( \pm 2.15)$ \\
$\begin{array}{l}\text { Toys } \\
\text { Newspapers and magazines }\end{array}$ & 0.9 & 8.1 & $2.7( \pm 2.00)$ \\
$\begin{array}{l}\text { Books } \\
\text { School support and supervision }\end{array}$ & 0 & 8 & $4.2( \pm 1.84)$ \\
Organization of schedules & 0 & 10 & $5.8( \pm 1.64)$ \\
Family gathered for routine & 0 & 10 & $6.9( \pm 2.52)$ \\
activities & & & \\
Total RAF & 16.9 & 72.3 & $47.6( \pm 12.55)$ \\
\hline
\end{tabular}


schedules, and support and supervision for school activities. Children's participation in extracurricular activities was the event least pointed out by the participants.

The correlation analysis between emotional and behavioral symptoms with the presence of resources in the home environment (Table 5) showed negative associations between the presence of symptoms and resources, the more symptoms, the fewer resources are present. On the other hand, the more the child showed prosocial behaviors, the more access they had to different opportunities. The RAF dimensions organization of schedules and family gathered for routine activities showed no significant correlation with SDQ subscales. School support and supervision by the family were associated significantly only with impact supplement results. The strongest correlations were noted between recreational activities at home or neighborhood with relationship problems with peers and impact supplement (which also correlated with RAF' total result), having toys, and the scores of behavior problems and total of the SDQ.

\section{DISCUSSION}

The present study aimed to identify what resources were offered in the daily life of children with mental disorders and, from this, verify whether the offer of such resources in the family microsystem was associated with areas of greatest damage relative to mental health problems.

The theoretical framework adopted allows us to make important considerations about the child focused, in a risk condition for the development on the whole, in the face of the presence of the mental disorder ${ }^{38}$, and the predominance of boys ${ }^{39,40}$, who stem from families of less privileged economic stratum ${ }^{41,42}$. We identified a set of conditions that increased these children's vulnerability to the worsening of existing mental health problems, as well as to the establishment of other problems. Corroborating this statement, it was observed that a portion of children (21.8\% - almost one-quarter of the sample), though schoolaged, did not attend school, and that worsened even more their situation. Although a risk condition alone may not have harmful effects on development, it has the potential to trigger a mechanism that leads to other negative experiences, producing cumulative effects on child development $t^{3,38}$.

In this sense, the perception of those responsible for the children (most mothers and main caregiver) that the behavioral and emotional difficulties present harmed routine activities at home, friendships, learning, and leisure, draws our attention. For that matter, one study brings evidence that problems stemming from child mental disorder extend to other contexts, outside the family ${ }^{43}$. Considering the exchanges between the developing subject and the environment are bidirectional, mutual, and dynamic ${ }^{3}$, it seems plausible to suppose that the child mental disorder effects on the different environments, impact the child himself, establishing a cycle that feeds into pre-established risk mechanisms ${ }^{44}$.

In what concerns the exclusion of the child from the school context, such a condition might present itself as a barrier to development because, according to the literature, the school routine promotes development in interactions with peers and the participation and support of those responsible for the child, in this context ${ }^{10,45-47}$.

The establishment of positive proximal processes, promoters of healthy development, can configure itself, particularly in this context, as a protective factor, and opens up the possibility of breaking with the vulnerability cycle and achieving a more adaptive trajectory and developmental result. In this sense, results indicate the presence of favorable

Table 5. Significant results of the association between difficulties and strengths (SDQ) and family environment resources (RAF)

\begin{tabular}{|c|c|c|c|c|c|c|c|}
\hline \multirow[t]{2}{*}{ Resources } & \multicolumn{7}{|c|}{$\begin{array}{l}\text { Subscales referring to difficulties and strengths } \\
\text { Correlation coefficient ( } r \text { ) }\end{array}$} \\
\hline & ES & CP & H & $\mathbf{R}$ & PS & Total & IS \\
\hline $\begin{array}{l}\text { Recreational activities at home/ } \\
\text { neighborhood }\end{array}$ & -0.013 & $-0.589^{\star \star}$ & $-0.533^{\star \star}$ & $-0.657^{\star *}$ & $0.503^{* *}$ & $-0.487^{\star \star}$ & $-0.695^{* *}$ \\
\hline Family outings & -0.295 & -0.341 & $-0.414^{*}$ & $-0.462^{\star *}$ & $0.419^{\star}$ & $-0.452^{\star *}$ & $-0.594^{* *}$ \\
\hline Scheduled and regular activities & -0.233 & -0.105 & -0.033 & $-0.356^{\star}$ & 0.223 & -0.333 & $-0.389^{*}$ \\
\hline Joint activities with parents at home & -0.095 & -0.304 & $-0.432^{*}$ & -0.186 & $0.346^{\star}$ & -0.245 & $-0.441^{*}$ \\
\hline Toys & -0.270 & $-0.633^{\star \star}$ & $-0.517^{\star \star}$ & -0.266 & 0.318 & $-0.625^{\star \star}$ & $-0.474^{\star *}$ \\
\hline Newspapers and magazines & $-0.406^{\star}$ & -0.188 & -0.054 & -0.020 & 0.096 & -0.252 & -0.144 \\
\hline Books & $-0.445^{\star \star}$ & $-0.392^{\star}$ & $-0.392^{*}$ & -0.230 & $0.347^{\star}$ & $-0.557^{\star \star}$ & $-0.451^{\star \star}$ \\
\hline School support and supervision & -0.061 & -0.201 & -0.340 & -0.319 & 0.292 & -0.234 & $-0.454^{\star *}$ \\
\hline Organization of schedules & -0.265 & 0.059 & -0.232 & 0.020 & 0.162 & -0.093 & -0.269 \\
\hline Family gathered for routine activities & -0.154 & 0.235 & -0.033 & -0.025 & 0.023 & 0.074 & -0.073 \\
\hline Total RAF & -0.332 & $-0.400^{\star}$ & $-0.527^{\star \star}$ & $-0.364^{*}$ & $0.439^{*}$ & $-0.502^{* *}$ & $-0.618^{\star *}$ \\
\hline
\end{tabular}

SDQ: strengths and difficulties questionnaire; ES: emotional symptoms; CP: conduct problems; H: hyperactivity; R: relationship problems with peers; PS: prosocial behavior; IS: impact supplement. ${ }^{*}<<0.05$; ** $p<0.01$. 
environmental resources: toys that make it possible for the child to interact not only with the object (to play), but meanings that pervade it (to perform roles in a play, for example) and with the others present in the environment (with whom he plays); carrying out of routine activities with other people of the family; activities carried out with the parents, and homework support and supervision. All these situations point to the potential occurrence of periods of interaction between the child and another person, which extend over time and repeat in daily life (proximal processes) ${ }^{3}$.

It should be pondered that, with respect to the carrying out of activities with parents or other family members, in the case of children with mental disorder, these situations might not always be characterized by positive and quality interactions. A follow-up study of child psychopathology throughout time, identified that children with high rates of hyperactivity and relationship problems with peers require intense monitoring and interventions including the family ${ }^{48}$. On the other hand, the interaction with family members, mediated by the toy, favors better developmental outcomes ${ }^{3,49}$. The existence of resources itself might not be favoring to the engagement of the families in activities with the child, there is a need for additional strategies that may be more inviting, such as adapted or more inclusive activities both from the educational and social perspective ${ }^{32}$.

In the core of the present study, results from the associations identified indicate that the more severe the difficulty shown by the child, the lower the availability of resources. On the other side, the more the prosocial behavior is present, the greater the access to different opportunities. There is a suggestion that the environment organizes itself as per the child's behavior. For example, the higher the scores of behavior and hyperactivity problems the fewer toys. The family might feel discouraged to offer toys to children showing externalizing behaviors, for the following two reasons: the child often destroys his toys or uses them in aggressive attitudes against himself or the others ${ }^{50}$.

A similar process seems to occur as to doing recreational activities, whether at home or in the neighborhood, and family outings, in that the child's behavior can provoke discomfort in the environment and the family might feel constrained. However, those resources are, too, more limited for children with relationship difficulties with peers and, in this case, the family might be attending to the child himself, who prefers to be alone, has no friends, or even protecting him from being disturbed by other people. In both situations, it is important to consider that the mental disorder brings with it a stigma, which affects in a particular way children with the problem ${ }^{51}$. Additionally, it is possible that in the face of the child's difficulties and limitations, a feeling of shame emerges in the parents or the practice of overprotection, which ends up decreasing the possibilities of the child establishing interactions in other environments ${ }^{52}$.
The decrease of school support and supervision as well as of books as the symptoms or the mental disorder impact increase in different contexts, might be related to the number of children outside school or to the fact that some children have cognitive and educational deficits, and might not receive tasks from school. The literature has affirmed repeatedly the association between difficulties in learning and mental health problems in childhood ${ }^{53,54}$.

A result that deserves particular attention concerns the prosocial behavior results among the children studied. This behavior dimension has been neglected in studies with clinical samples, whose analyses turn to symptoms and difficulties ${ }^{27,55}$. However, there is evidence that prosociality has a negative association with externalizing behaviors ${ }^{56,57}$ and positive with good emotional regulation ${ }^{58}$.

Future studies could investigate the social skills profile of children with mental disorder, the mechanisms by which this type of behavior can relate to the mental disorder, test strategies to strengthen possible protecting effects in these skills in the presence of mental disorder, and assess how those behaviors can be allied to and approached in the treatment of mental disorders in childhood. We highlight that studies have pointed out that social skills, in contexts of typical development, configure themselves as a protection factor for development ${ }^{59,60}$.

Investigations should be carried out to verify how the interactions with different members of the family have been established. Once proximal processes present themselves as a key aspect for development, it is important to know the quality of those interactions. The present study shows that there are resources offered in the home environment, though in a limited way, however, it has not provided information on the motivation to perform or not different activities with the child, and how existing resources (toys, books, family outings) are used to promote sociability, learning, and better child results. In fact, a limitation in this study is in not having dedicated itself to such deepening.

Another limitation is in considering the view of one person responsible only and not including a broader investigation on emotional and behavioral difficulties shown by the children, which could bring more detail to the analysis of associations between environmental resources and externalizing and internalizing behaviors. Moreover, a qualitative analysis, caseto-case, could elucidate what weighs more on the family's resource offer: difficulties or the child's strengths.

Although with a reduced sample, the results allow to reflect on the home environment resources in light of the Bioecology of development, with special attention to proximal processes, which also led to the choice of investigation instrument (RAF). It was possible to understand in this way the importance of offering such resources, especially for the population assisted. Thus, the implications of the study lie in the possible contribution to assistance networks within the 
health and social context of these children and families, with the intent of aiding in therapeutics and rights relative to them.

\section{CONCLUSIONS}

Results show that there are resources present in the family environment that can contribute to the development of children with a mental disorder, however, this availability is affected by the type of behavior or difficulty shown by the child. Furthermore, we highlight that these children have positive personal characteristics (prosocial behaviors), which could be strengthened as protection factors for development. Greater attention should be given to how the family members manage the environment and their interactions with the child with a mental disorder, considering the needs of both - child and family.

\section{AUTHORS' CONTRIBUTIONS}

Eduarda Souza Dilleggi - Collected, analyzed, interpreted participants' data in the outpatient clinics, as well as contributed in writing the manuscript.

Patricia Leila dos Santos - Was one of the main contributors in writing and revising the manuscript.

Fabio Scorsolini-Comin - Contributed in writing and revising the manuscript. All authors read and approved the final manuscript.

\section{CONFLICTS OF INTEREST}

The authors declare that they have no conflicts of interests.

\section{ACKNOWLEDGEMENTS}

We are grateful to all families and to the team of the Service of Child and Adolescent Psychiatry that contributed to the study. We also wish to thank the research collaborators who helped with data collection. We thank Capes (Comissão de Aperfeiçoamento de Pessoal do Nível Superior) for the graduate fellowship granted to the senior author.

\section{REFERENCES}

1. Agirregoikoa A, Acha, J, Barreto-Zarza, F, Arranz-Freijo, EB. Family Context Assessment to Promote Language and Reading Abilities in 6-Year-Old Children. Educ Sci. 2021;11(26):1-13.

2. Barreto FB, Miguel MS, Ibarluzea J, Andiarena A, Arranz E. Family context and cognitive development in early childhood: A longitudinal study. Intelligence. 2017;65:11-22.

3. Bronfenbrenner U. Bioecologia do desenvolvimento humano: tornando os seres humanos mais humanos. Porto Alegre, RS: Artmed; 2011.
4. Tudge J, Rosa E, Payir A. Bioecological model. In: M. Bornstein (Ed.). The SAGE encyclopedia of lifespan human development. Thousand Oaks, CA: SAGE Publications, Inc.; 2018. p. $251-2$.

5. Gerstein ED, Crnic KA. Family Interactions and Developmental Risk Associated With Early Cognitive Delay: Influences on Children's Behavioral Competence. J Clin Child Adolesc Psychol. 2018:47(S1):S100-12.

6. Caputi M, Lecce S, Pagnin A. The role of mother-child and teacher-child relationship on academic achievement. Eur J Develop Psychol. 2017;14(2):141-58.

7. McLaughlin KA. Future Directions in Childhood Adversity and Youth Psychopathology. Clin Child Adolesc Psychol. 2016; 45(3):361-82.

8. Diab SY, Palosaari E, Punamäki R. Society, individual, family, and school factors contributing to child mental health in war: The ecological-theory perspective. Child Abuse Negl. 2018;84:205-16.

9. Atilola 0. Child mental-health policy development in sub-Saharan Africa: broadening the perspectives using Bronfenbrenner's ecological model. Health Promot Int. 2017;32(2):380-91.

10. Monteiro RM, Santos AAA. Recursos familiares e desempenho de crianças em compreensão de leitura. Psico. 2013:44(2):273-9.

11. Ferreira SHA, Barrera SD. Ambiente familiar e aprendizagem escolar em alunos da educação infantil. Psico. 2010;41(4):462-72

12. Cid MFB. Cotidiano familiar: refletindo sobre a saúde mental infantil e a prática de atividades familiares. Rev Ter Ocup USP. 2015;26(3):428-38.

13. Oliveira EA, Barros FC, Anselmi LD, Piccinini CA. The quality of home environment in Brazil: A ecological model. J Child Fam Stud. 2006;15(5):631-42.

14. Leme VBR, Marturano EM. Predictors of children's behavior problems and academic competence of nuclear separated and remarried. Psicol Reflex Crít. 2014;27(1):153-62.

15. Adolph KE, Kretch KS. Gibson's theory of perceptual learning. In: Keller H (Ed.). International encyclopedia of the social and behavioral sciences. New York, NY: Elsevier; 2015. v. 10, p. $127-34$.

16. Bradley RH, Putnick DL. Housing quality and access to material and learning resources within the home environment in developing countries. Child Develop. 2012:83(1):76-91.

17. Marturano EM. 0 inventário de Recursos do Ambiente Familiar. Psicol Reflex Crít. 2006:19(3):498-506.

18. Polanczyk GV, Salum GA, Sugaya LS, Caye A, Rohde LA. Annual Research Review: A metaanalysis of the worldwide prevalence of mental disorders in children and adolescents. J Child Psychol Psychiatry. 2015;56(3):345-65.

19. Thiengo DL, Cavalcante MT, Lovisi GM. Prevalence of mental disorders among children and adolescents and associated factors: a systematic review. J Bras Psiquiatr. 2014;63(4):360-72.

20. Paula CS, Miranda CT, Bordin IAS. Saúde mental na infância e adolescência: revisão dos estudos epidemiológicos brasileiros. In: Lauridsen-Ribeiro EPP, Tanaka OY (Orgs.). Atenção em saúde mental para crianças e adolescentes no SUS. São Paulo, SP: Hucitec; 2010. p. $75-92$

21. Salum GA, Gadelha A, Pan PM, Moriyama TS, Graeff-Martins AS, Tamanaha AC, et al. High risk cohort study for psychiatric disorders in childhood: rationale, design, methods and preliminary results. Int J Methods Psychiatr Res. 2015;24(1):58-73.

22. Dias NM, Pontes JM, Silva LDP, Mecca TP. Relations between theory of mind and family environment among Brazilian preschool children. Appl Neuropsychol Child. 2021;10:1-9.

23. Johnson J, Perrigo JL, Deavenport-Saman A, Wee (P, Imagawa KK, Schonfeld DJ, et al. Effect of home environment on academic achievement in child protective service-involved children: Results from the second national survey of child and adolescent well-being study. Child Abuse Negl. 2021;111:104806.

24. Pires TO, Silva CMFP, Assis SG. Association between family environment and attention deficit hyperactivity disorder in children - mothers' and teachers' views. BMC Psychiatry. 2013;13(215):1-9.

25. Muniz EL, Silver EJ, Stein REK. Family routines and social-emotional school readiness among preschool-age children. J Dev Behav Pediatr. 2014;35(2):93-9.

26. Rutter M. How the environment affects mental health. Br J Psychiatry. 2005;186:4-6.

27. Del Bianco Faria AM, Cardoso CL. Stress in caregivers of children with attention-deficit hyperactivity disorder. Psico. 2016;47(3):228-37.

28. Cheung C, Lwin K, Jenkins JM. Helping youth in care succeed: Influence of caregiver involvement on academic achievement. Child Youth Serv Rev. 2012;34(6):1092-100. 
29. Conn AN, Szilagyi MA, Jee SH, Blumkin AK, Szilagyi PG. Mental health outcomes among child welfare investigated children: In-home versus out-of-home care. Child Youth Serv Rev. 2015;57:106-11.

30. Cruvinel M, Boruchovitch E. Depressive symptoms in children and family environment. Psicol Pesq. 2009;3(1):87-100.

31. Glynn LM, Davis EP, Luby UL, Baram TZ, Sandman CA. A predictable home environment may protect child mental health during the COVID-19 pandemic. Neurobiol Stress. 2021;14:1-7.

32. Kavousipor $S$. Which aspects of Child Development are Related to the Home Environment?: A Narrative Review. J Rehabil Sci Res. 2019;6:1-5.

33. Mindell JA, Williamson AA. Benefits of a bedtime routine in young children: sleep, development, and beyond. Sleep Med Rev. 2018;40:93-108.

34. Morilla CM, Caldas CACT, Scarpellini ACAV, Santos PL. Family resources and promotion of development of children with cerebral palsy. J Hum Growth Dev. 2017;27(2):166-74.

35. Associação Brasileira de Empresas de Pesquisa (ABEP). Critério de Classificação Econômica Brasil. 2015. Available from: http://www.abep.org. Accessed on: June 8, 2021.

36. Fleitlich B, Cortazar PG, Goodman R. Questionário de Capacidades e Dificuldades (SDQ). Infanto. 2000;8(1):44-50.

37. Hulley SB, Cumming SR, Browner WS, Grady DG, Hearst NB, Newman TB. Delineando a pesquisa clínica: uma abordagem epidemiológica. 2ª ed. Porto Alegre: Artmed; 2003.

38. Evans GW, Whipple SS, Li D. Cumulative risk and child development. Psychol Bull. 2013;139(6).1342-96.

39. Dalsgaard S, Thorsteinsson E, Trabjerg BB, Schullehner J, Plana-Ripoll O, Brikell I, et al. Incidence rates and Cumulative Incidences of the Full Spectrum of Diagnosed Mental Disorders in Childhood and Adolescence. JAMA Psychiatry. 2020;77(2):155-64.

40. Masi A, DeMayo, MM, Glozier, N, Guastella AJ. An Overview of Autism Spectrum Disorder, Heterogeneity and Treatment Options. Neurosci Bull. 2017;33(2):183-93.

41. Machlin L, McLaughlin KA, Sheridan MA. Brain structure mediates the association between socioeconomic status and attention-deficit/hyperactivity disorder. Dev Sci. 2020;23(1):e12844.

42. Reiss F, Meyrose AK, Otto C, Lampert T, Klasen F, Ravens-Sieberer U. Socioeconomic status, stressful life situations and mental health problems in children and adolescents: Results of the German BELLA cohort-study. PLoS One. 2019;14(3):e0213700.

43. McDonald SW, Kehler HL, Tough SC. Risk factors for delayed social-emotional development and behavior problems at age two: Results from the All Our Babies/Families (AOB/F) cohort. Health Sci Rep. 2018;1(10):e82.

44. Rutter M. Resilience as a dynamic concept. Dev Psychopathol. 2012;24:335-44.

45. Pereira S, Santos JN, Nunes MA, Oliveira MG, Santos TS, Martins-Reis V0. Health and education: a partnership required for school success. CoDAS. 2015;27(1):58-64.

46. Dessen MA, Polonia AC. A família e a escola como contextos de desenvolvimento humano. Paideia. 2007;17(36):21-32.
47. Mayfield CA, Child S, Weaver RG, Zarrett N, Beets MW, Moore JB. Effectiveness of a playground Intervention for Antisocial, Prosocial, and Physical Activity Behaviors. J School Health. 2017;87(5):338-45

48. O'Connor C, Reulbach U, Gavin B, Mcnicholas F. A prospective longitudinal investigation of the (dis)continuity of mental health difficulties between mid-to late-childhood and the predictive role of familial factors. Eur Child Adolesc Psychatry. 2018;27:289-300.

49. Tonetto LM, Pereira AS, Koller SH, Bressane K, Pierozan D. Designing Toys and Play Activities for the Development of Social Skills in Childhood. Design J. 2020;23(2):199-217.

50. Yan N, Ansari A, Wang Y. Intrusive parenting and child externalizing behaviors across childhood: The antecedents and consequences of child-driven effects. J Fam Psychol. 2019;33(6):661-70

51. Kaushik A, Kostaki E, Kyriakopoulos M. The stigma of mental illness in children and adolescents: A systematic review. Psychiatry Res. 2016;243:469-94.

52. Vicente JB, Mariano PP, Buriola AA, Paiano M, Waidman MAP, Marcon SS. Aceitação da pessoa com transtorno mental na perspectiva dos familiares. Rev Gaúcha Enferm. 2013;34(2):54-61.

53. Tzuriel D, Shomron V. The effects of mother-child mediated learning strategies on psychological resilience and cognitive modifiability of boys with learning disability. Br J Educ Psychol. 2018;88(2):236-60.

54. Panicker AS, Chelliah A. Resilience and Stress in Children and Adolescents with Specific Learning Disability. J Can Acad Child Adolesc Psychiatry. 2016;25(1):17-23.

55. Farias CA, Lima POC, Ferreira LA, Cruzeiro ALS, Quevedo LA. Sobrecarga em cuidadores de usuários de um centro de atenção psicossocial infanto-juvenil no Sul do Brasil. Ciênc Saúde Coletiva. 2014;19(12):4819-27.

56. Obsuth I, Eisner MP, Malti T, Ribeaud D. The developmental relation between aggressive behaviour and prosocial behaviour: A 5-year longitudinal study. BMC Psychol. 2015:3(16):1-15.

57. Nantel-Vivier A, Pihl RO, Côté S, Tremblay RE. Developmental association of prosocial behaviour with aggression, anxiety and depression from infancy to preadolescence. J Child Psychol Psychiatry. 2014;55(10):1135-44.

58. Hein S, Röder M, Fingerle M. The role of emotion regulation in situational empathy-related responding and prosocial behaviour in the presence of negative affect. Int J Psychol. 2018;53(6):477-85.

59. Bolsoni-Silva AT, Loureiro SR, Marturano EM. Behavior problems and children social skills: report modalities. PSICO. 2011:42(3):354-61

60. Casali-Robalinho IG, Del Prette ZAP, Del Prette A. Social skills as predictors of problem behavior in school children. Psicol Teor Pesq. 2015;31(3):321-30. 